\title{
USE OF STABLE ISOTOPES IN THE DETERMINATION OF THE MEAN ALTITUDE OF RECHARGE AND THE INVESTIGATION OF FUNCTION MECHANISM OF SPRING WATERS IN ARGOLIS PENINSULA (GREECE)
}

\author{
Matiatos I. ${ }^{1}$, Alexopoulos A. ${ }^{1}$, and Zouridakis N. ${ }^{2}$ \\ ${ }^{1}$ University of Athens, Faculty of Geology and Geoenvironment, 15784 Athens, Greece, \\ imatiatos@geol.uoa.gr,aalexopoulos@geol.uoa.gr \\ ${ }^{2}$ NCSR Demokritos, Isotope Hydrology Laboratory, Aghia Paraskevi, 15310 Athens, Greece, \\ nizouri@chem.demokritos.gr
}

\begin{abstract}
In the present study, the isotopic composition $\left(\delta^{18} O\right)$ of several spring waters in Argolis peninsula is examined. The use of the specific isotope aimed at the determination of the altitude of recharge areas, while the credibility of the extracted results was verified by in situ geological observations. The applied methodology included the construction of a linear diagram which correlates the stable isotopic values $\left(\delta^{18} \mathrm{O}\right)$ in meteoric waters and the altitude. Isotopic data, concerning meteoric waters, came from: a) rain gauge stations of GNIP network (IAEA/WMO), b) rain tanks and selected wells located in Mt. Arachnaio, $c$ ) improvised rain collectors which were put in several sites in the peninsula. A decrease of $0.45 \% \circ \delta^{18} \mathrm{O}$ per $100 \mathrm{~m}$ altitude was determined. The average isotopic composition of the examined springs, as far as $\delta^{18} \mathrm{O}$ is concerned, resulted from 14 sampling periods between October 2005 and March 2008. This ${ }^{18} \mathrm{O}$-content of spring waters was used to derive the recharge area and consequently to evaluate the mechanism of water renewal.
\end{abstract}

Key Words: hydrogeology, stable isotopes, Argolis peninsula, mean altitude of recharge.

\section{Introduction}

Isotopes which are naturally produced and incorporated into the hydrological cycle are often referred to as "Environmental Isotopes". The methodologies that were based on naturally occurring isotopes (stable and radioactive) were used for various hydrogeological problems encountered in water resources assessment which led to the establishment of a scientific field known as "Isotope Hydrology".

In particular, stable isotopes, such as Oxygen-18 can have several applications in hydrogeology (Schiavo et al., 2009; Bono et al., 2007; Trabelsi et al., 2007; Boronina et al., 2005; Majumdar et al., 2005; D’ Alessandro et al., 2004; Yurtsever \& Araguas, 1993) such as:

- The determination of groundwater system boundaries.

- The identification of hydraulic connections between an aquifer and surface waters or between different aquifer units.

- The study of origin (genesis) of water and the delineation of processes involved (process tracing) 
during flow and circulation of water.

- The determination of the source(s), the processes and the rate of replenishment in groundwater systems.

- The evaluation of the dynamics of geothermal systems.

- The identification of the source(s) and the mechanisms of salinization in coastal aquifers.

The contribution of stable isotopes in the investigation of groundwater movement is based on the isotopic content of atmospheric waters, because the major changes in the isotopic composition of natural waters occur in the atmospheric part of the water cycle (Yurtsever \& Gat, 1981). Therefore, the subsurface waters "inherit" the isotopic characteristics of the meteoric water inputs and further change a little, except as a result of mixing with waters of a different origin and composition. From this point of view, stable isotopes can work as ideal tracers. Among the factors that affect the isotopic composition of atmospheric waters and subsequently groundwater is the altitude (Sharp, 2007; Clark \& Fritz, 1997). This parameter, known as "altitude effect", is significantly useful in hydrogeology because it gives us the opportunity, on one hand, to distinguish the groundwater coming from small or high altitudes and on the other hand to determine the mean altitude of recharge (Tazioli, 2007).

\section{Geological setting}

The geological status in Argolis peninsula differs notably in comparison to the rest of the Peloponnese, because it consists of a wide variety of geological formations which, as far as the facies is concerned, are similar to those of several stratigraphic units. Moreover, the sudden change of lithology is attributed either to tectonics or a rough transition of statigraphy. In addition, the substantial lithological heterogeneity in horizontal and vertical direction leads to the appearance of many individual springs mostly of small capacity.

According to Bortolloti et al. (2002a, 2003), the geological setting of the study area comprises of (Fig.1):

- Neritic limestones of Trapezona, which become pelagic with cherts in places, while in the upper parts they are covered by coarse-grained carbonate and ophiolitic breccias (Baumgartner, 1985). In the lower parts, volcanic formations were identified at many sites (Renz, 1906b, Gaitanakis \& Photiades, 1991).

- An ophiolitic mélange consisting of pillow lavas and dolerites and locally of cherts, siltstones, serpentinised mafic and ultramafic rocks.

- A tectonic mélange characterized mainly by the presence of silts, sandtones and marls which occupies the largest part of Adheres mountain ridge. In this matrix, big turbiditic rocks of different lithology such as volcanic rocks, radiolarites, limestones, granodiorites (Photiades \& Keay, 2000), pyroclastic rocks, andesites, dolomites (Aranitis, 1963), quartz sandstones, serpentinites and basalts (Clift \& Robertson, 1989) are present.

- A "post-Ypresian" flysch which represents alterations of calcareous schists, marls, sandy marls, sandstones, conglomerates and limestones and covers mainly the Nafplio-Lygourio basin (Baumgartner, 1985; Kantas, 1991).

- Neritic limestones which successively become pelagic in the upper parts followed by marls and flysch ("Akros formation", according to Decrouez, 1975). At the bottom of the formation, a tectonic mélange (Iliokastron area) of "sheared" serpentinites and clastic slices of several rocks such as dunits, basalts, cherts and limestones (Gaitanakis \& Photiades, 1993, Photiades \& Economou, 


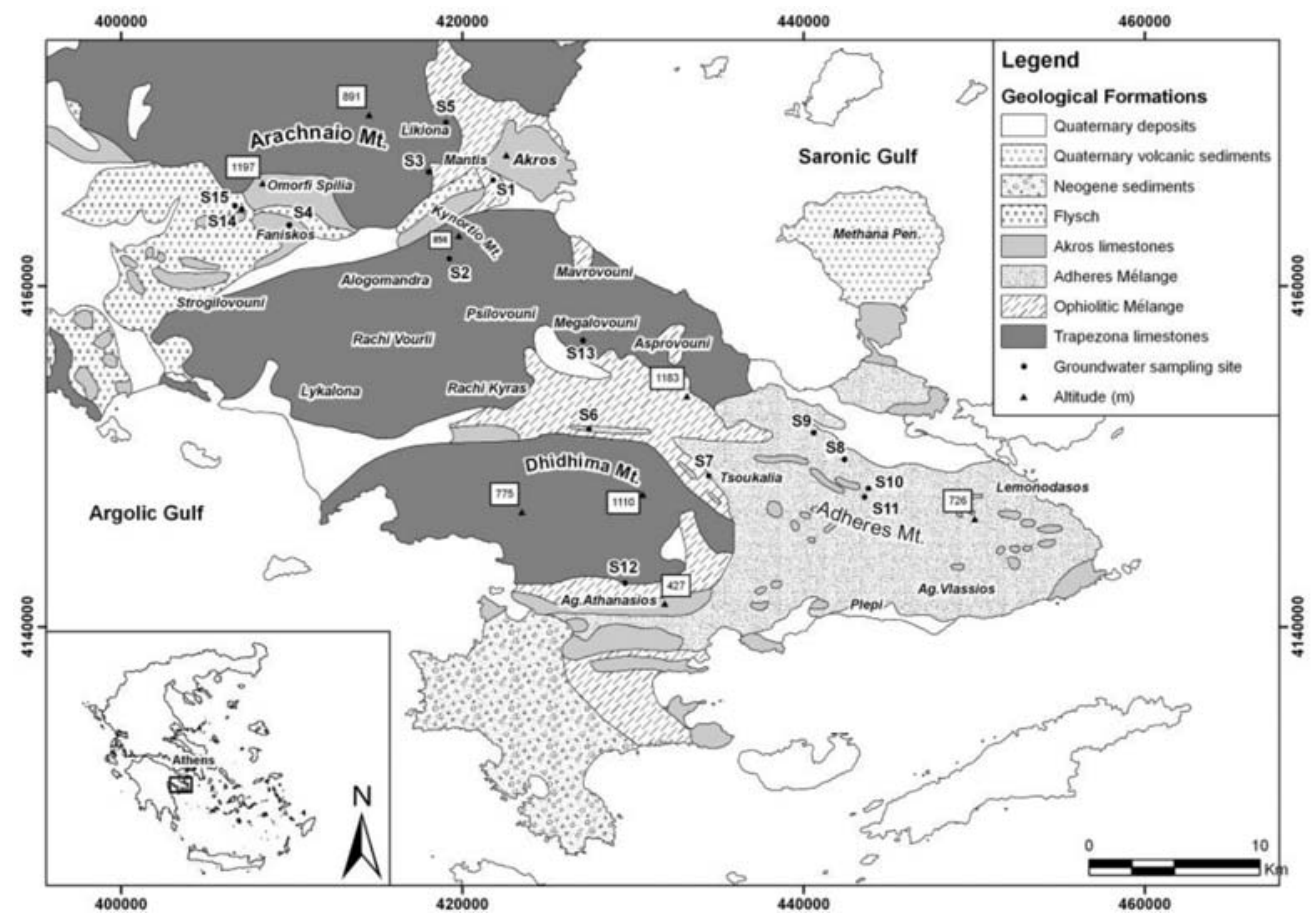

Fig. 1: A simplified geological map of the study area (modified after Clift \& Dixon, 1998) and the location of the groundwater sampling sites.

1991) is present.

- Neogene deposits of Miocene - Pliocene age occupying the Porto Cheli-Kranidi geological trough, in the southwestern part of the peninsula (Gaitanakis \& Photiades, 2007). The sequence includes calcareous marls, marly limestones and conglomerates with sandstones intercalations. The pebbles of the conglomerates which origin from the weathering of sandstones, limestones and parts of the ophiolitic mélange are lying inside a calcareous sandstone matrix.

- A quaternary volcanic formation consisting of loose volcanic sediments with tuff blocks and dacide and andesite domes (Fytikas, 1980), covering almost the entire Methana peninsula.

- Recent deposits comprising of alluvial fans, debris cones and loose sediments of silts, sands and pebbles.

\section{Methods}

\subsection{General}

The orography represents a substantial factor in the rise and the adiabatic freezing of water vapors, which induces the occurrence of precipitation events. At higher altitudes, where the temperature is decreasing, the rain is expected to be more depleted in heavy isotopes and therefore the values of $\delta^{18} \mathrm{O}$ will be more negative (Clark \& Fritz, 1997). In the area under study, the altitude effect of the precipitation on isotopic composition has been obtained by using data coming from: a) four rain gauge stations (Thission, Patras, Pendeli and Hellinikon) from the Global Network of Isotopes in Precipitation (G.N.I.P.) constructed by the International Atomic Energy Agency (I.A.E.A.) in coopera- 


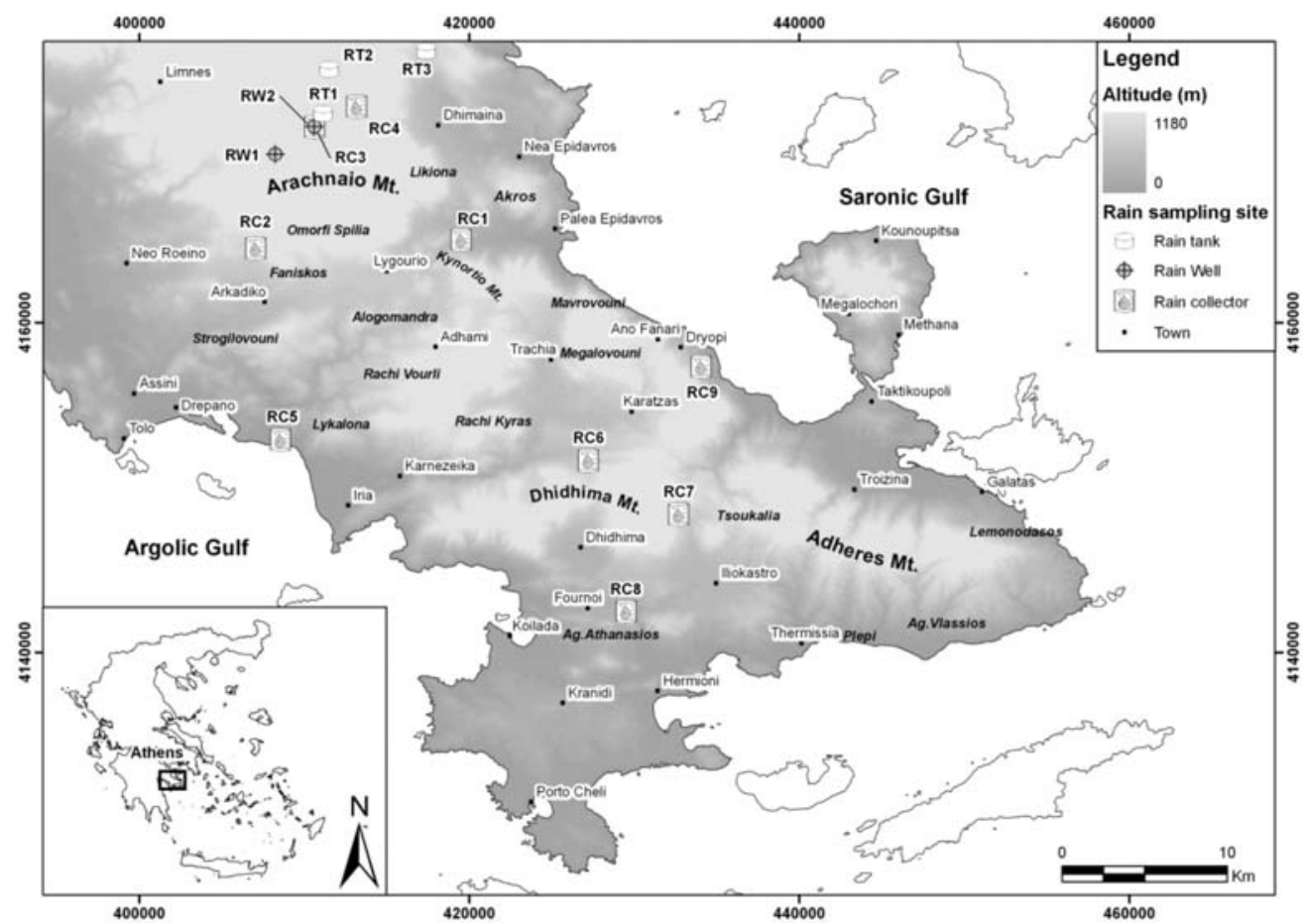

Fig. 2: Topographic map of the study area and the location of rain sampling sites.

tion with World Meteorological Organization (W.M.O.), b) three rain tanks (sites: RT1, RT2 and RT3, and selected wells (sites: RW1 and RW2) in Mt. Arachnaio, c) nine improvised rain collectors (sites: RC1-RC9) (Fig.2). In order to evaluate their mean altitude of recharge, fifteen groundwater sites (springs) in the peninsula were repeatedly sampled during the period between October 2005 and March 2008 (Fig.1).

The sampling from the rain tanks, the wells and the springs was carried out on a monthly basis, and the samples were collected in $20 \mathrm{ml}$ polyethylene containers which were firstly rinsed in clear water several times and then filled to the top to minimize air entrapment. At the same time, these specific bottles contained a special membrane which halters the occurrence of evaporation phenomena. After the samples were tightly sealed, they were stored in a portable fridge until they were transported to the laboratory for the isotopic analyses.

In order to obtain supplemental information concerning the isotopic signature of meteoric waters in the region, we constructed nine rain collectors according to the instructions given by the I.A.E.A. In particular, we used 5-litre polyethylene vessels with a funnel adapted to each sample container, so as to increase the gathering area of the rain water. Moreover, we put medical paraffin oil in every vessel, in order to avoid evaporation until the samples were collected. The medical paraffin oil layer floating over the water had a thickness of about $0.5 \mathrm{~cm}$. The sampling of the rain collectors was performed on a monthly basis and the rain water was transferred in similar to the aforementioned $20 \mathrm{ml}$ polyethylene bottles, which were then transported to the laboratory.

The stable isotope ratios $\left({ }^{18} \mathrm{O} /{ }^{16} \mathrm{O}\right)$ were measured at the Isotope Hydrology Laboratory of N.C.S.R. "Demokritos", Athens, Greece. The ${ }^{18} \mathrm{O} /{ }^{16} \mathrm{O}$ ratios were defined with the help of an Isotope Ratio 
Table 1. Mean isotopic composition of rain water according to the gauge stations from the GNIP network (IAEA/WMO).

\begin{tabular}{|c|c|c|c|c|}
\hline Station & $\mathbf{X}$ & $\mathbf{Y}$ & $\boldsymbol{\delta}^{\mathbf{1 8}} \mathbf{O}(\%)$ & Altitude (m) \\
\hline Hellinikon & 476113.6 & 4194466.6 & -5.80 & 27 \\
\hline Patras & 306546.9 & 4238905.0 & -5.21 & 100 \\
\hline Thission & 475257.7 & 4202235.8 & -6.13 & 107 \\
\hline Pendeli & 488152.7 & 4211083.5 & -7.72 & 498 \\
\hline
\end{tabular}

Table 2. Mean isotopic data of rain water obtained by the rain tanks (RT) and the wells (RW) located in the highlands of Mt. Arachnaio. The sampling period is between October 2005 and March 2008.

\begin{tabular}{|c|c|c|c|c|}
\hline Site & $\mathbf{X}$ & $\mathbf{Y}$ & $\boldsymbol{\delta}^{\mathbf{1 8}} \mathbf{O}(\boldsymbol{\%})$ & Altitude (m) \\
\hline RT1 & 411147.0 & 4172668.0 & -7.22 & 798 \\
\hline RT2 & 411499.0 & 4175356.0 & -6.33 & 687 \\
\hline RT3 & 417381.0 & 4176467.0 & -5.23 & 370 \\
\hline RW1 & 408243.0 & 4170203.0 & -6.66 & 641 \\
\hline RW2 & 410616.0 & 4171869.0 & -6.94 & 712 \\
\hline
\end{tabular}

Mass Spectrometer (SIRA Series II) $\left(\mathrm{CO}_{2}\right.$ equilibrated) and then were expressed in $\delta \%$, i.e. per mille deviation vs. the reference V-SMOW. The measurements standard uncertainties are $0.1 \%$ for $\delta^{18} \mathrm{O}$. The validity of the results was obtained by the repetition of the measurements and their comparison with respective isotopic analyses carried out in foreign laboratories (i.e. Environmental Isotope Laboratory-University of Arizona-USA) to which several samples were sent.

\subsection{Data analysis}

The applied methodology aimed, initially, at the construction of a line which represents the relation between the isotopic content $\left(\delta^{18} \mathrm{O}\right)$ of precipitation and the altitude at the collection site, for each of the three sampling groups (GNIP network, rain tanks and wells, rain collectors). All the imported data concerned long-term mean values of $\delta^{18} \mathrm{O}$, while at the second stage of the processing, we were able to derive from the three lines an average rate of isotopic depletion with altitude.

The selection of the specific stations (Hellinikon, Patras, Thission, Pendeli) from GNIP network (Table 1) was based on the fact that they showed the longest and most complete time series from all the available stations, while at the same time they are located closer to the study area. The long term mean $\delta^{18} \mathrm{O}$ values of Hellinikon, Patras and Thission stations resulted from monthly measurements, while those of Pendeli station from rainfall event measurements. Moreover, for the mean isotopic concentration of Pendeli station we included the $\delta^{18} \mathrm{O}$ values given by Argiriou \& Lykoudis (2006), for the same station and for the period 2000-2003.

The data obtained from the rain tanks have the advantage that they represent long-term mean values, because the rain water is gathered in them during the whole year. The two wells, that were included in this sampling group, are located in the same area with the rain tanks (Table 2). The selection of the two wells was based on the fact that the collected water comes from the immediate storage of the meteoric water. The in situ hydrogeological observations along with the measured electrical con- 
Table 3. Mean isotopic composition of rain water based on rain collectors (RC) located throughout the Argolis peninsula. The sampling period is between October 2006 and April 2007.

\begin{tabular}{|c|c|c|c|c|}
\hline Rain Collector & $\mathbf{X}$ & $\mathbf{Y}$ & $\mathbf{\delta}^{\mathbf{1 8}} \mathbf{O}(\%)$ & Altitude (m) \\
\hline RC1 & 419512.0 & 4165023.2 & -4.88 & 132 \\
\hline RC2 & 407049.7 & 4164484.1 & -6.13 & 413 \\
\hline RC3 & 410622.8 & 4171866.4 & -6.87 & 716 \\
\hline RC4 & 413167.8 & 4173089.5 & -6.86 & 820 \\
\hline RC5 & 408549.0 & 4152884.7 & -4.03 & 18 \\
\hline RC6 & 427198.6 & 4151617.2 & -6.32 & 300 \\
\hline RC7 & 432677.1 & 4148344.2 & -6.10 & 490 \\
\hline RC8 & 429510.7 & 4142465.8 & -4.43 & 127 \\
\hline RC9 & 434053.7 & 4157307.5 & -5.14 & 175 \\
\hline
\end{tabular}

ductivity of the water verified that the groundwater in the aquifer originates as local recharge. In particular, the wells are constructed in a terra rossa plain with no lithological alterations which resulted by the weathering of the carbonate formations covering Mt. Arachnaio. In addition, their depth is small, and the electrical conductivity of the gathered water does not exceed $100 \mu \mathrm{S} / \mathrm{cm}$, just like the water in the rain tanks. Similar electrical conductivity values are mentioned by Nastos et al. (2007) in rain water samples collected at several locations across Greece.

As far as the nine rain collectors are concerned, the mean values of $\delta^{18} \mathrm{O}$ came from data recorded on a monthly basis during the period between October 2006 and April 2007 (Table 3). The installation of the rain collectors was based on several criteria such as the different elevations, the best spatial allocation and the collection of rain water which falls on recharge areas of some of the groundwater sampling sites.

The average $\delta^{18} \mathrm{O}$ content in precipitation is plotted against the altitude for each data group in Fig.3. The three dashed lines were determined by the method of least squares and gave a similar rate of $\delta^{18} \mathrm{O}$ depletion with altitude. From these lines we extracted the regression line $\mathrm{AB}$ which defines the overall relation of the two parameters and whose slope led to the determination of an average rate of $-0.45 \%$ o $\delta^{18} \mathrm{O} / 100 \mathrm{~m}$. This value places among the ranges of $-0.15 \%$ ond $-0.50 \%$ (Clark \& Fritz, 1997) and $-0.10 \%$ o $\omega \varsigma-0.60 \%$ (Mook, 2005) per 100-m rise in altitude given for the most parts around the world.

It should be mentioned that the calculated ratio is approximately given, so the more data concerning meteoric waters, is added the more reliable the result will be. Scientific studies have proven that the rate of depletion of $\delta^{18} \mathrm{O} / 100 \mathrm{~m}$ can also vary on a seasonal basis, as the isotopic content is related to the origin of air masses that affect the area as well as to the sampling period (Bortolami et al. 1979, Payne \& Yurtsever 1974).

In order to estimate the mean altitude of recharge of the springs, we plotted on a $\delta^{18} \mathrm{O}$ versus altitude diagram the line $\mathrm{AB}$ which represents the average rate of depletion, together with the groundwater sampling points. The pair of values for the latter concerned their long-term mean isotopic content of $\delta^{18} \mathrm{O}$ and the elevation at the site of the sampling (Fig.4).

From the relation developed and illustrated in Fig.4, we observe that the majority of the groundwa- 


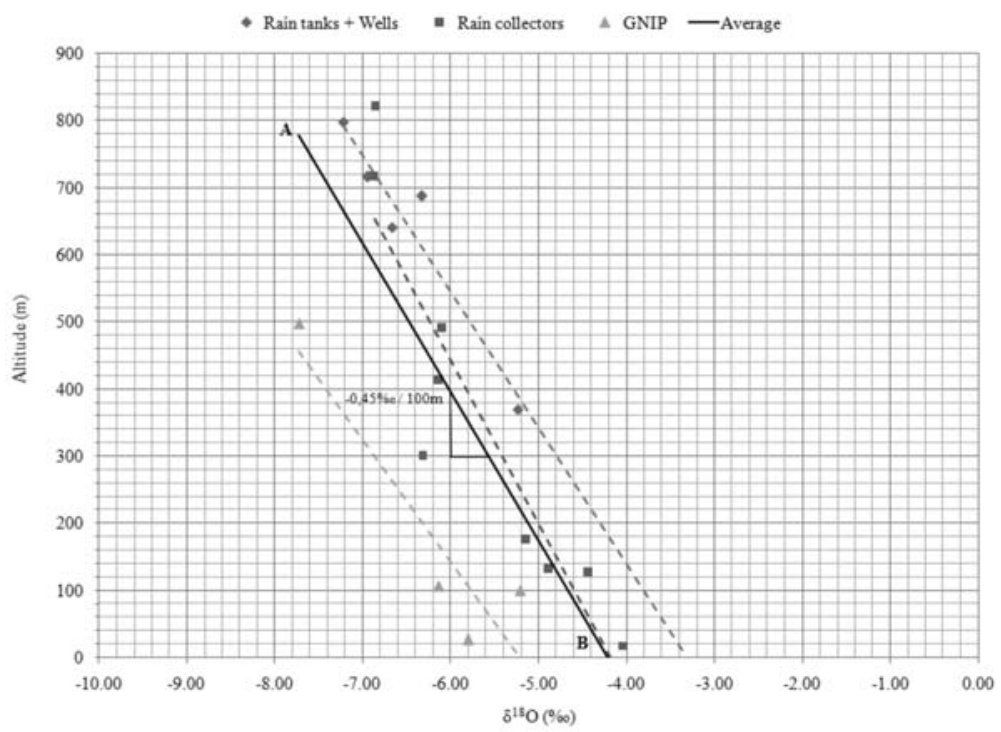

Fig. 3: Diagram of mean $\delta^{18} \mathrm{O}$ values in rain water versus elevation at the collection site derived from the three sampling groups.

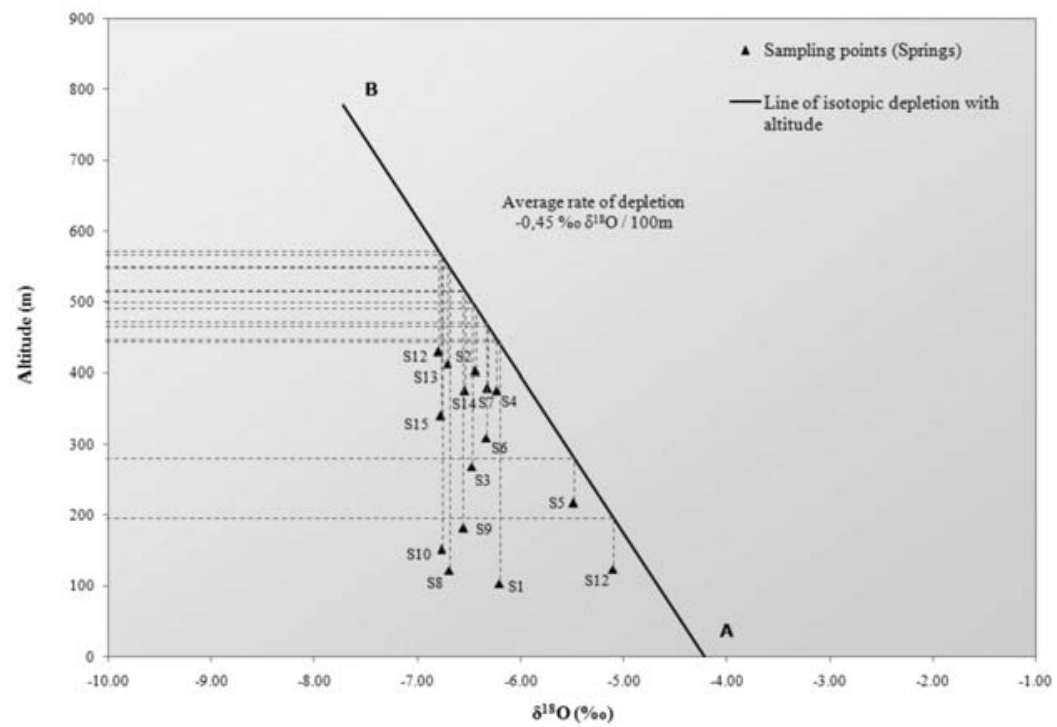

Fig. 4: Diagram of mean $\delta^{18} \mathrm{O}$ values in groundwater samples versus the altitude. A decrease of $0.45 \%$ o $\delta^{18} \mathrm{O}$ per $100 \mathrm{~m}$ altitude is typical for the study area.

ter samples are located beneath the line $\mathrm{AB}$, which means that their mean altitude of recharge is most likely to be higher than the altitude at the sampling site. The points that are very close to the line show that the mean altitude of the intake area is almost the same with the elevation of sampling, which means that the replenishment of these springs probably takes place locally. On the contrary, the springs plotted very far from the line underline that they are mainly recharged from much higher altitudes than the one of the sampling site. 
Table 4. Mean altitude of recharge $(\mathrm{m})$ of the groundwater sampling sites (springs) as it derived from the linear diagram of Figure 4.

\begin{tabular}{|c|c|c|c|c|c|}
\hline $\begin{array}{c}\text { Sampling } \\
\text { site }\end{array}$ & $\boldsymbol{\delta}^{\mathbf{1 8}} \mathbf{O}(\mathbf{\% o})$ & $\begin{array}{c}\text { Mean altitude of } \\
\text { recharge (m) }\end{array}$ & $\begin{array}{c}\text { Sampling } \\
\text { site }\end{array}$ & $\boldsymbol{\delta}^{\mathbf{1 8}} \mathbf{O}(\%)$ & $\begin{array}{c}\text { Mean altitude of } \\
\text { recharge (m) }\end{array}$ \\
\hline S1 & -6.21 & 442 & S9 & -6.56 & 519 \\
\hline S2 & -6.44 & 493 & S10 & -6.77 & 566 \\
\hline S3 & -6.47 & 500 & S11 & -5.10 & 567 \\
\hline S4 & -6.23 & 447 & S12 & -6.80 & 198 \\
\hline S5 & -5.48 & 282 & S13 & -6.71 & 573 \\
\hline S6 & -6.34 & 471 & S14 & -6.54 & 553 \\
\hline S7 & -6.32 & 467 & S15 & -6.77 & 516 \\
\hline S8 & -6.69 & 549 & & & \\
\hline
\end{tabular}

As it is depicted in the diagram above, in order to calculate the mean altitude of recharge of the studied springs, we drew from each point a line parallel to the altitude axis until it intersects with the line $\mathrm{AB}$. From the intersection point we drew a second line parallel to $\delta^{18} \mathrm{O}$ axis until it touches the altitude axis. The derived value corresponds to the mean altitude of recharge of the sampling point. All the results of the aforementioned procedure are given in Table 4.

\section{Conclusions-Results}

The extracted mean altitude of the intake area of the springs under study, as it was defined with the help of oxygen isotope ratios, is in agreement with real topographic, geological and hydrogeological setting, according to in situ observations. In particular, spring S1 is mainly replenished by Mantis area (450m), part of the southwestern edges of Akros Mountain, while spring S2 is recharged by the southwestern part of Kynortio Mountain $(500 \mathrm{~m})$ located very close to the ancient theatre of Epidaurus. Moreover, the water in spring S3 origins from the southeastern edges of Arachnaio Mountain $(500 \mathrm{~m})$, in spring S4 from the eastern side of Faniskos mass $(460 \mathrm{~m})$ and in spring S5 from the eastern verge of Arachnaio Mountain, from an area called Likiona $(300 \mathrm{~m})$. Spring S6 recharges from the northern part of Dhidhima ridge $(500 \mathrm{~m})$, spring S7 from the hilly area of Tsoukalia (480m), while springs S8, S9, S10 and S11 from independent aquifer units on Adheres mountain ridge (560m, $520 \mathrm{~m}, 580 \mathrm{~m}$ and $580 \mathrm{~m}$ respectively). The water in spring S12 origins from the mountainous area of Ag. Athanasios (200m), in spring S13 from Megalovouni Mountain (580m) and in springs S14 and S15 from the southern part of Arachnaio Mountain and specifically from an area called Omorfi Spilia (560m and $520 \mathrm{~m}$ respectively).

To sum up, the use of isotopic methods in hydrogeology contributes significantly to the solution of problems and the investigation of physical procedures that are difficult to confront with the conventional ways of study. In particular, the application depends primarily on the estimation of the isotopic content $\left(\delta^{18} \mathrm{O}\right)$ of meteoric waters of a certain geographic area and allows the determination of the mean altitude of recharge of groundwater reservoirs. However, the results should be verified by in situ geological observations. Therefore, even if the Argolis peninsula is a region which is not characterized by an intense relief, the application of stable isotopes methodology led to the identification of the areas that replenish a series of springs in the peninsula, which coincides absolutely with the geological explanation, as far as the function mechanism is concerned. 


\section{References}

Aranitis, S., 1963. Die Entstehung der Eruptivgesteine yon Hermioni-Gebiet und die mit ihnen verbundenen Vererzung, Ann. Geol. Pays Hell. 14, 211-323.

Argiriou, A. A. \& Lykoudis, S., 2006. Isotopic composition of precipitation in Greece, Journal of Hydrology 327, 486-495.

Baumgartner, P.O., 1985. Jurassic sedimentary evolution and nappe emplacement in the Argolis Peninsula (Peloponnesus, Greece), Mém Soc. Helv. Sci. Nat. 99,1-111.

Bono, P., Brun, C., Fiori, C., Gonfiantini, R. \& Zucco, F., 2007. The use of oxygen and deuterium in the water dynamics assessment of two lakes in the volcanic structure of mount vulture, southern Italy, Proceedings, Advances in Isotope Hydrology and its Role in Sustainable Water Resources Management (IHS-2007), Vienna, Austria, Vol. 2, pages: 165-173.

Boronina, A., Balderer, W., Renard, P., and Stichler, W., 2005. Study of stable isotopes in the Kouris catchment (Cyprus) for the description of the regional groundwater flow, Journal of Hydrology 308, 214-226.

Bortolami, G. C., Ricci, B., Susella, G. F. and Zuppi, G. M., 1979. Isotope hydrology of the Val Corsaglia, Maritime Alps, Piedmont, Italy, In Isotope Hydrology 1978, Vol. I., IAEA Symposium 228, June 1978, Neuherberg, Germany: 327-350.

Bortolotti, V., Carras, N., Chiari, M., Fazzuoli, M., Marcucci, M., Photiades, A. \& Principi, G., 2002 a. New geological observations and biostratigraphic data on the Argolis Peninsula: Palaeogeographic and geodynamic implications, Ofioliti 27 (1), 43-46.

Bortolotti, V., Carras, N., Chiari, M., Fazzuoli, M., Marcucci, M., Photiades, A. \& Principi, G., 2003. The Argolis Peninsula in the palaeogeographic and geodynamic frame of the Hellenides, Ofioliti 28 (2), 79-94.

Clark, I. D. \& Fritz, P., 1997. Environmental Isotopes in Hydrogeology, Lewis Publishers, New York, pp. 328.

Clift, P.D. \& Robertson, H. F., 1989. Evidence of a late Mesozoic ocean basin and su bduction-accretion in the southern Greek Neo-Tethys, Geology 17, 559-563.

Clift, P.D. \& Dixon, J. E., 1998. Jurassic ridge collapse, subduction initation and ophiolite obduction in the southern Greek Tethys, Eclogae geol. Helv. 91, 128-138.

D’ Alessandro, W., Federico, C., Longo, M. \& Parello, F., 2004. Oxygen isotope composition of natural waters in the Mt Etna area, Journal of Hydrology 296, 282-299.

Decrouez, D., 1975. Etude statigraphique et micropaleontologique du Cretace d'Argolide (Peloponnese, Grece), These Univ. Geneve, pp. 259.

Fytikas, M., Innocenti, F. \& Mazzuoli, R., 1980. Methana sheet-Geological map in scale 1:500000, IGME, Greece.

Gaitanakis, P. \& Photiades, A.D., 1991. Geological structure of SW Argolis (Peloponnesus, Greece), Bull. Geol. Soc. Greece 25 (1), 319-338.

Gaitanakis, P. \& Photiades, A.D., 1993. New data on the geology of Southern Argolis (Peloponnesus, Greece), Bull. Geol. Soc. Greece 28 (1), 247-267.

Gaitanakis, P. \& Photiades, A. D., 2007: Spetses sheet-Geological map in scale 1:50000, IGME, Greece.

Kantas, K., 1991. Hydrogeological explanation of salt-water intrusion in karstic aquifers in the NE Argolis limestones (Peloponnesus, Greece), Bull. Geol. Soc. Greece 25 (4), 183-201.

Majumdar, N., Majumdar, R.K., Mukherjee, A.L., Bhattacharya, S.K. \& Jani, R.A., 2005. Seasonal variations in the isotopes of oxygen and hydrogen in geothermal waters from Bakreswar and Tantloi, Eastern India: implications for groundwater characterization, Journal of Asian Earth Sciences 25, 
269-278.

Mook, W.G., 2005. Introduction to Isotope Hydrology, Taylor \& Francis, 288p.

Nastos P.T., Alexakis, D., Kanellopoulou, H.A. \& Kelepertsis, A.E., 2007. Chemical composition of wet deposition in a Mediterranean site Athens, Greece related to the origin of air masses, J. Atm. Chem. $58,167-179$.

Payne, B.R. \& Yurtsever, Y., 1974. Environmental isotopes as a hydrogeological tool in Nicaragua. In Isotope Techniques in Groundwater Hydrology 1974, IAEA, Vienna, 1, 193-202.

Photiades, A.D. \& Ecomomou, G. S., 1991. Alteration hydrothermale sous-marine des basaltes et des dolerites (facies zeolitique) de l' unite moyenne "volcanique" de l' Argolide septentrionale, (Peloponnese, Grece), Bull. Geol. Soc. Greece 25 (2), 301-319.

Photiades, A.D. \& Keay S., 2000. Mid-Late Jurassic granodiorite basement in southern Argolis Peninsula (Greece): tectonostratigraphic implications. In Panayides, I., Xenophontos, C. and Malpas, J. (eds), 2000, Proceedings of the Third International Conference on the Geology of the Eastern Mediterranean, Geol. Surv. Dpt. Cyprus, 233-239.

Renz, C. 1906b. Trias und Jura in der Argolis, Zeitschrifi der Deutschen Geologirchen Gesellenschaft 58, 379-395.

Schiavo, M.A., Hauser, S., \& Povine, P.P., 2009. Stable isotopes of water as a tool to study groundwaterseawater interactions in coastal south-eastern Sicily, Journal of Hydrology 364, 440-449.

Sharp, Z., 2007. Stable Isotope Geochemistry, Pearson Education, USA, pp. 344.

Tazioli, A., Mosca, M. \& Tazioli, G. S., 2007. Location of recharge area of Gorgovivo spring, central Italy, Proceedings, Advances in Isotope Hydrology and its Role in Sustainable Water Resources Management (IHS-2007), Vienna, Austria, Vol. 2, pages: 27-35.

Trabelsi, R., Charfi, S., Chkir, N., Abidi, B. \& Zouari, K., 2007. Contribution of isotopic indicators to the assessment of groundwater mixture between Continental Intercalaire and Djeffara aquifers (Southeastern Tunisia), Proceedings, Advances in Isotope Hydrology and its Role in Sustainable Water Resources Management (IHS-2007), Vienna, Austria, Vol. 2, pages: 9-17.

Yurtsever, Y. \& Gat, J.R., 1981. Atmospheric waters. In Gat JR, Gonfiantini R. (eds) Stable Isotope Hydrology: Deuterium and oxygen-18 in the water cycle, IAEA Tech Rep Ser 210, 103-142.

Yurstever, Y. \& Araguas Araguas, L., 1993. Environmental isotope applications in hydrology: an overview of the IAEA's activities, experiences, and prospects, Tracers in Hydrology (Proceedings of the Yokohama Symposium, July, 1993), IAHS Publ. no. 215.

IAEA: http://nds121.iaea.org/wiser. 